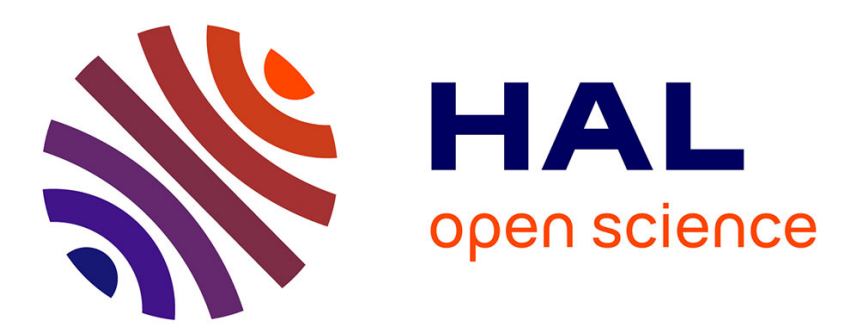

\title{
9th IEEE EMBS International Summer School on Biomedical Imaging 2010: From cells to clinics [A Look
} At]

Jean-Louis Dillenseger, Valérie Burdin, Christian Roux, Guy Cazuguel, Jean-Louis Coatrieux

\section{To cite this version:}

Jean-Louis Dillenseger, Valérie Burdin, Christian Roux, Guy Cazuguel, Jean-Louis Coatrieux. 9th IEEE EMBS International Summer School on Biomedical Imaging 2010: From cells to clinics [A Look At]. IEEE pulse, 2011, 2 (1), pp.48 - 54. 10.1109/MPUL.2010.939611 . inserm-00585306

\section{HAL Id: inserm-00585306 https://www.hal.inserm.fr/inserm-00585306}

Submitted on 7 Sep 2011

HAL is a multi-disciplinary open access archive for the deposit and dissemination of scientific research documents, whether they are published or not. The documents may come from teaching and research institutions in France or abroad, or from public or private research centers.
L'archive ouverte pluridisciplinaire HAL, est destinée au dépôt et à la diffusion de documents scientifiques de niveau recherche, publiés ou non, émanant des établissements d'enseignement et de recherche français ou étrangers, des laboratoires publics ou privés. 


\title{
From cells to clinics
}

\section{9th IEEE EMBS International Summer School on Biomedical Imaging 2010}

\author{
Jean-Louis Dillenseger ${ }^{1,2}$, Valérie Burdin ${ }^{3,4}$, Guy Cazuguel $^{3,4}$, Christian Roux ${ }^{3,4}$, Jean-Louis \\ Coatrieux $^{1,2}$ \\ ${ }^{1}$ INSERM U642, Laboratoire Traitement du Signal et de l’Image, 35042 Rennes, France \\ ${ }^{2}$ Université de Rennes I, 35042 Rennes, France \\ ${ }^{3}$ INSERM U650, Brest, France \\ ${ }^{4}$ Institut TELECOM - TELECOM Bretagne, Laboratoire de Traitement de l'Information \\ Médicale, Brest, France
}

The 9th edition of the Summer School (June 18-26) has been held on Berder island, Brittany, France. Berder is part of the natural park of the Gulf of Morbihan (i.e "little sea" in britton, recognized as belonging to the 100 most beautiful bays of the world. All the week the weather has been wonderful and allowed having lunch and dinner outside the Manor.

These 9 working days have been very successful thanks to the exceptional lectures that have addressed many important topics of the Biomedical Imaging field. The talks of Mathias Fink (ESPCI ParisTech, France) were focused on "Multi-wave Imaging" with acoustic as a major area. Dimitris Metaxas (Rutgers University, USA) developed his most recent research work on "Learning and Stochastic Deformable Model-based Methods for Clinical and Preclinical Applications" with in particular applications to heart diseases. Jean-Christophe Olivo-Marin (Institut Pasteur, France) surveyed the current state-of-the art through his lectures on "Quantitative Biological Imaging: from Cells to Numbers" with impressive results on cell tracking. Jerry Prince (Johns Hopkins University, USA) addressed the still challenging issue of medical image processing through his presentations on "Segmentation and Labeling in Neuroimaging". Marco Viceconti (University of Bologna, Italy) has shown using orthopaedics as target how imaging and modelling biomechanics can be coupledto improve the functional joint understanding and to derive specific patient solutions, a key issue currently supported by the European Commission under the "Virtual Physiological Human project”. A. Claude Boccara (ESPCI ParisTech, France) illustrated the way in which physics can help to create new imaging techniques, especially optical imaging at various scales through homogeneous or complex media, such as human and animal tissues. He also sketched fascinating topics such as the combination of optics and ultrasound.

The tradition of the IEEE EMBS school is to offer to one of the past-participants to come back as Junior lecturer. The candidates have to submit a proposal on a topic not addressed by the key lecturers. This year, 2 Juniors have been exceptionally selected because of they were equally defended by the members of the selection committee. Lilla Zöllei (Massachusetts General Hospital, USA) displayed new methods dealing with robust and accurate alignment of structural MRI images and diffusion tractography. Efstathios Hadjidemetriou (Freiburg University Hospital, Germany) presented his work in-progress respectively on the analysis of longitudinal MRI data monitoring for preclinical and clinical treatment trials. The junior 
lecturers' venue has been sponsored by the Métivier Foundation, Rennes, France (http://metivier.irisa.fr/index.html).

For this 2010 edition, 37 participants were selected by an international committee based on CVs and motivation letters. They were coming from 21 countries disseminated all over the world, including Argentina, Belorussia, China, India and Singapore. Grants were proposed in order for them to attend the school. The active contribution of all participants plays a key role in the success of Berder Summer School. All students have presented their research work along the four poster sessions that they have organized and run themselves. All expressed their enthusiasm for the Summer School which offers a forum to learn and exchange with all the participants and the lecturers, all things difficult in conferences. The interdisciplinary nature of the school with links with biology, physiology, physics, etc is also a major feature of the school.

This year again, after the poster presentations, a competition has been organized by the attendees themselves for the Poster Award, supported by SFGBM, the French Biomedical Engineering Society (http://sfgbm.enst-bretagne.fr/). The winner has been Adityo Prakosa (India, presently at Inria Sophia, France) for “Analysis and Simulation of Heart Function”. The award consists in cash and a commitment to publish a paper in the journal IRBM of the SFGBM.

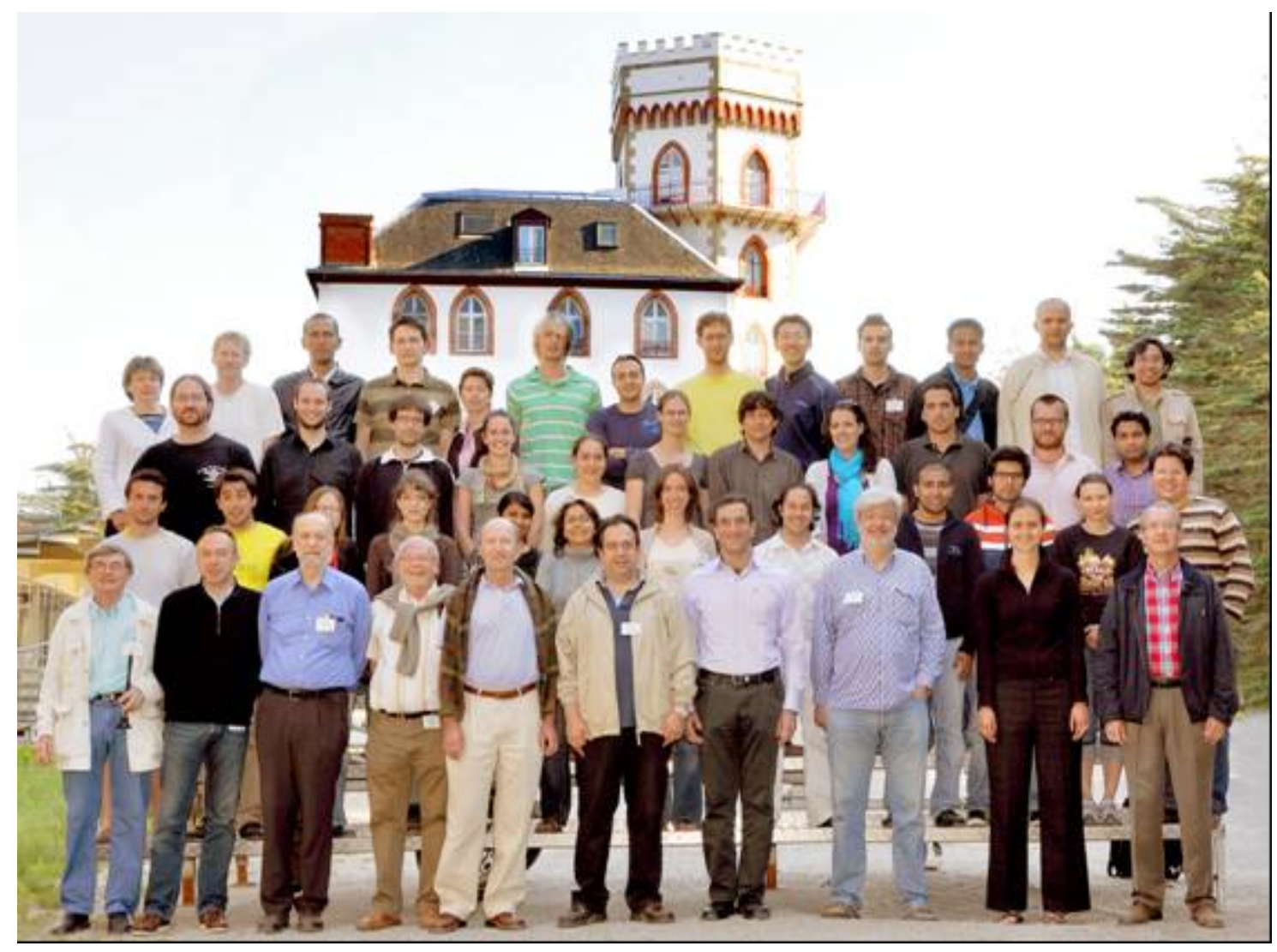

The social activities were the counterpart of the intensive work during sessions and discussions. From the Welcome dinner to the Farewell evening and night, time slots were available for boat ride or kayaking over the Morbihan's Gulf, for a visit to the Carnac megalithic alignments and to the Old City of Vannes. 
The materials related to the 9th Summer School have been included in two documents which were made available on-site: (1) a booklet gathering the CVs and pictures of the lecturers (with abstract of their lectures) and the participants; (2) a CD ROM gathering the all materials related to the lectures including original introductions by each lecturer and selected papers.

The organization of this 9the edition of the Summer School would not have been possible without the help of numerous persons and sponsors. The lecturers have been heavily involved in the preparation of the proceedings and of their presentations, and have been very keen on spending time and energy during the various informal and interactive periods. The students who, as always, have created a unique atmosphere of motivation and fun. Several contributions were instrumental in the organization of this edition of the Summer School, in particular those of Katell Morin-Hernandez (Rennes) and Gwenaël Brunet (Brest).

This edition was sponsored and granted by the IEEE Engineering in Medicine and Biology Society (EMBS) and supported by the CEA-DTA-LETI (France). Significant institutional sponsoring and grants were provided by the French Ministry for Research, the National Institute of Health and Medical Research (Inserm), the Métivier Foundation, the Institut Telecom, the Universities Joseph Fourier (Grenoble) and Rennes 1 as well as TelecomBretagne. The French Biomedical Engineering Society (SFGBM) has played a major role in its setting together with the Medical Information Processing Laboratory (LaTIM, Inserm, Brest) and the Signal and Image Processing Laboratory (LTSI, Inserm, Rennes). We are also pleased to acknowledge the sponsorship of the Regional Council of Brittany. The several grants served to offer reduced fees mainly for attendees coming from developing countries.

The 9th International School was an excellent opportunity to not only bring imaging fundamentals but also some insights on the emerging technologies, their new targets and needs. It is thought that most has still to be achieved when dealing with biomedical imaging and that engineering should contribute to the expected breakthroughs. The ways to follow are so many that anybody, as far as a well-posed question is set (either based on biological or clinical concerns), can find her or his path.

After all, in its highest meaning, life is learning, creating, innovating, and the IEEE EMBS Summer School on Biomedical Imaging has been designed to only serve such objective. The School relies on volunteering contributions and, thanks to the lecturers for this 2010 edition and many others in the past, it will continue. Christian Roux and his team will make it alive for 2012 (June 22-30). Any information can be obtained by contacting Valérie Burdin (valerie.burdin@telecom-bretagne.eu).

9th IEEE EMBS International Summer School on Biomedical Imaging.

Website : $\underline{\text { http://ieeess.enst-bretagne.fr }}$ 